\title{
Manufacture or Assemble Software Platform or Architecture for in Vitro Diagnostics Device
}

National Cancer Institute

\section{Source}

National Cancer Institute. Manufacture or Assemble Software Platform or Architecture

for in Vitro Diagnostics Device. NCI Thesaurus. Code C113019.

Fabrication of the physical structure of an in vitro diagnostic device. 